\title{
Filarial complement-fixation test for pulmonary tropical eosinophilia with Ascaris antigen
}

\author{
G. L. ROBINSON AND MOYNA CHRISTIAN \\ From the Dreadnought Seamen's Hospital, Greenwich, London
}

SYNOPSIS A trial of antigen prepared from Ascaris lumbricoides in the complement-fixation test for pulmonary tropical eosinophilia and for filariasis is described. No significant difference was observed between this antigen and that prepared from Dirofilaria immitis.

The disease which has come to be known as pulmonary tropical eosinophilia (Weingarten, 1943) has been commonly found in India and Malaya, though it has also been described elsewhere in the tropics. In its tropical (especially coastal) origin and in its failure to resolve spontaneously it differs from the similar condition known as Löffler's syndrome or eosinophilic lung. It affects in Britain only persons recently living in the tropics, and, above all, Indian seamen, among whom 37 cases have been diagnosed in this hospital during the last six years. Once discriminated from other forms of asthmatic bronchitis, pulmonary tropical eosinophilia may be cured by hetrazan, which has now replaced the original (also effective) intravenous arsenical treatment. It is thus an important disease to diagnose with accuracy, and this may be difficult with Indian seamen, whose histories are not adequate, whose eosinophilia may be due to intestinal helminths, and whose bronchi suffer from their change of climate. All inpatients are screened for eosinophilia by the use of special diluting fluid (Randolph and Stanton, 1945) in routine total white cell counts. The diagnosis then turns mainly on the association of eosinophilia which is high with asthmatic bronchitis. But confirmation by the filarial complement-fixation test has been found of great value. Originally Dr Ridley kindly performed these tests for us, using Dirofilaria immitis antigen (Ridley, 1956), then tests were tried here with extracts of the round worm Ascaris lumbricoides as being the nearest relation to the filarioids easily obtainable in large quantity.

\section{MATERIALS AND METHODS}

ANTIGEN Fresh Ascaris lumbricoides worms were washed, snipped into bits, and dried in a hot fan blast. Thorough

Received for publication 28 September 1967. grinding with sand in ethanol (about $10 \mathrm{ml}$ per worm) was followed by incubation at $37^{\circ} \mathrm{C}$, shaking daily, for 옹 three weeks. After filtration through Whatman 40 paper, the fluid was stored at $4^{\circ} \mathrm{C}$, refiltering if necessary. The $\bar{z}$ working strength of various batches determined by chessboard titration with positive and negative sera and 2 MHD complement, was found to be about 1 in 250 and with 3 MHD complement was about 1 in 40 .

TEST All four reagents (serum, antigen, complement, and sensitized cells) were used in $0.16 \mathrm{ml}$ volumes. Sera were tested in rows of doubled dilutions from 1 in 5 to 1 in 320 in glass tubes, $11 \mathrm{~mm}$ diameter. Complement $\frac{\mathrm{Q}}{\mathbb{Q}}$ strength was 2 MHD. Incubation time was $60 \mathrm{~min}$ on the bench, then $60 \mathrm{~min}$ on a bath at $37^{\circ} \mathrm{C}$ before cells $\overrightarrow{\overrightarrow{0}}$ were added. The usual type of barbitone-buffered saline, $\exists$ with added $\mathrm{Mg}$ and $\mathrm{Ca}$, was used as diluting fluid. Reactions of control sera from local antenatal clinics occasionally reached a dilution of 1 in 15 , which was therefore taken as the critical level: readings were con- 8 sidered negative below 1 in 15 and positive above it. $\overline{-}$ Finally, it was decided that test conditions employing about 1 in $\mathbf{4 0}$ antigen with 3 MHD of complement and a 8 critical serum titre of 1 in 5 would have been slightly more convenient than the more dilute method actually used in all results with Ascaris antigen reported here.

\section{RESULTS}

Table I shows that of 202 tests the Dirofilaria $N$ antigen gave 149 negative (including 21 slight reactions) and 53 positive reactions, while the Ascaris antigen gave 156 negative and 46 positive reactions. Of the negative reactions, 137 coincided, though of the positive only 34 did so. Of nine cases of clinically diagnosed pulmonary tropical eosinophilia which were tested in parallel, all were positive with Ascaris but only seven with Dirofilaria antigen.

The smaller total number of positive results $\frac{?}{\mathbb{Q}}$ obtained with Ascaris compared with Dirofilaria antigen suggested that intestinal helminths were not 
TABLE I

NUMBERS OF SERA REACTING IN COMPLEMENT-FIXATION TEST WITH Dirofilaria AND Ascaris ANTIGENS

\begin{tabular}{llrlll} 
& \multicolumn{5}{c}{ Dirofilaria Antigen } \\
\cline { 3 - 6 } & & Negative & $\begin{array}{l}\text { Slight } \\
\text { Reaction }\end{array}$ & Positive & Total \\
\hline \multirow{2}{*}{ Ascaris antigen } & Negative & 121 & 16 & 19 & 156 \\
& Positive & 7 & 5 & 34 & 46 \\
& Total & 128 & 21 & 53 & 202
\end{tabular}

weighting the former figure. But when a larger series of results with Ascaris antigen was plotted against the presence or absence of faecal helminths (Table II), it appeared that a higher positive rate was associated with the presence of intestinal helminths $(20.9 \%$ compared with $13.6 \%)$. This could be due to the fact that both filariasis and

\section{TABLE II}

NUMBERS OF PATIENTS TESTED BY Ascaris COMPLEMENTFIXATION TEST AND FAECES EXAMINED FOR HELMINTHS

\begin{tabular}{lccc}
$\begin{array}{l}\text { Ascaris } \\
\text { Complement } \\
\text { fixation Test }\end{array}$ & \multicolumn{3}{l}{ Intestinal } \\
\cline { 2 - 4 } & Absent & Present & Strongyloides Larvae \\
\hline Negative & 293 & 347 & 34 \\
Positive & 46 & 92 & 22 \\
Positive (\%) & 13.6 & 20.9 & 39.3
\end{tabular}

intestinal helminthiasis tend to occur in the same environment. But a tendency was also noted for positive results to be associated with helminth fauna which included larvae of Strongyloides stercoralis. When such cases were extracted (Table II, column 3), it was seen that positive results had risen significantly to the level of $39 \cdot 3 \%$.

In Table III, results of the Ascaris complementfixation test are plotted against clinical diagnosis, assigned to filarial, non-filarial, and pulmonary tropical eosinophilic categories. Patients were mainly natives of the tropics, whose sickness brought them to hospital, and it was therefore not possible to include a similar category of normals. The doubtful group contained 118 cases which could not be certainly placed in either filarial or non-filarial groups although it contained a good deal of suspected but unproved filariasis. To this group were also assigned cases of idiopathic eosinophilia coming from regions where filariasis is prevalent. Cases in which a moderate eosinophilia was accompanied by intestinal helminths (or other known cause) were assigned to the non-filarial group. The positive rate of $37.3 \%$ in the doubtful group, lies, as expected, between that of the filarial and non-filarial groups. Cases of hydrocele with eosinophilia, provided they came from the eastern side of the Indian continent,
TABLE III

CORRELATION OF Ascaris COMPLEMENT-FIXATION TEST WITH CLINICAL DIAGNOSIS

\begin{tabular}{|c|c|c|c|c|}
\hline \multirow{2}{*}{$\begin{array}{l}\text { Ascaris } \\
\text { Complement- } \\
\text { fixation Test }\end{array}$} & \multicolumn{4}{|c|}{$\begin{array}{l}\text { Number of Cases Falling into Different } \\
\text { Diagnostic Groups }\end{array}$} \\
\hline & Filarial & Non-filarial & Doubtful & $\begin{array}{l}\text { Pulmonary } \\
\text { Tropical } \\
\text { Eosinophilia }\end{array}$ \\
\hline $\begin{array}{l}\text { Negative } \\
\text { Positive } \\
\text { Positive }\end{array}$ & $\begin{array}{r}5 \\
12\end{array}$ & $\begin{array}{l}705 \\
63\end{array}$ & $\begin{array}{l}74 \\
44\end{array}$ & $\begin{array}{r}2 \\
35\end{array}$ \\
\hline as $\%$ total & $70 \cdot 6$ & $8 \cdot 2$ & $37 \cdot 3$ & $94 \cdot 6$ \\
\hline
\end{tabular}

gave $100 \%$ positive results. Three Guinea worm cases all gave strongly positive results. It will be seen that this hospital receives few cases of classical filariasis, but a relatively large number of cases of pulmonary tropical eosinophilia, for which Table III records $94.6 \%$ positive results, thus substantiating the usefulness of the test for its main purpose. Too many tropical patients recorded in Table III gave unsubstantiated positive results to warrant using the test in a similar diagnostic manner for filariasis as for pulmonary tropical eosinophilia.

Normal control sera for the results in Table III were provided by local antenatal clinics: of 1,113 such sera, eight $(0.7 \%)$ were positive. The countries of origin of these eight mothers were Nigeria (4), Jamaica (2), Grenada (1), India (1): in other words, the test had probably selected seven filarial carriers from a thousand mothers in east London. In two of the Nigerians, microfilariae of $L$. loa were demonstrated. Europeans only gave false positive results in the very few cases when they were syphilitic, one being positive with Dirofilaria antigen also. The finding was checked by testing sera from VD clinics: those which reacted with Ascaris antigen were found to have titres of 1 in 50 or more in the cardiolipin Wassermann reaction. The reverse observation was also made: a positive cardiolipin Wassermann reaction was found to be associated with pulmonary tropical eosinophilia (as with glandular fever and malaria) in about a fifth of our cases, and to revert to normal after treatment. A high titre in the Reiter protein Wassermann reaction was not associated with a positive Ascaris complement-fixation test.

Since geography was evidently related to the Ascaris complement-fixation test results, patients have been roughly classified according to their native continent in Table IV, which shows a similar positive rate in the continents of India, Africa, and S. America with a lower one in the far East. Over three quarters of the cases are seen to have been Indians, and, as this group contains all the pul- 
monary tropical eosinophilia, their true filarial rate would be somewhat lower than that of the African group.

\section{TABLE IV}

\begin{tabular}{|c|c|c|c|c|}
\hline \multirow{2}{*}{$\begin{array}{l}\text { CORRELATION } \\
\text { Place of } \\
\text { Birth }\end{array}$} & \multicolumn{2}{|c|}{$\begin{array}{c}\text { OF Ascaris COMPLEMENT } \\
\text { WITH PLACE OF BIRTH }\end{array}$} & FIXATION & \multirow[t]{2}{*}{ TEST } \\
\hline & No. of Cases & $\begin{array}{l}\text { No. of Positive } \\
\text { Reactions }\end{array}$ & $\begin{array}{l}\text { Percentage } \\
\text { Positive }\end{array}$ & \\
\hline Europe & 117 & 2 & $1 \cdot 7$ & \\
\hline Africa & 89 & 19 & $21 \cdot 3$ & \\
\hline India & 703 & 137 & $19 \cdot 5$ & \\
\hline Far East & 67 & 4 & $6 \cdot 0$ & \\
\hline $\begin{array}{l}\text { Caribbean } \\
\text { and S. America }\end{array}$ & 34 & 6 & $17 \cdot 6$ & \\
\hline
\end{tabular}

DISCUSSION

The efficiency of the Ascaris complement-fixation test in the diagnosis of pulmonary tropical eosinophilia is shown by the figures in Table III, which also indicates that the test responds better to the antibody of this disease than to that of actual filarial infections, the titres being in fact much higher in the former as shown with Dirofilaria antigen by Danaraj, da Silva, and Schacher (1959). This is consistent with the allergic aetiology of the disease, experimentally confirmed by Buckley (1958) on a human volunteer. Microfilariae were absent from the blood in all our 37 cases.

One particular case $(044268)$ in our general series was of special interest because of an association of pain over the liver, including an episode of colic, with high eosinophilia (3,600 per cu $\mathrm{mm})$, strongly positive Ascaris and Dirofilaria complement-fixation tests, and striking failure to eradicate ascariasis by 11 courses of treatment (mainly Alcopar) over four months. Penetration of tissue by Ascaris lumbricoides was diagnosed after it was realized that Ascaris, by the misplaced use of tetrachlorethylene, had probably been stimulated. In fact, it seems that Ascaris climbed the bile duct and may even have given rise $\overrightarrow{\vec{F}}$ to liver abscess as described by Reay, Dignan, and Maunder (1964). Apart from penetration of the tissues by Ascaris itself, Strongyloides stercoralis $\overline{\bar{\sigma}}$ appeared the most antigenic intestinal parasite, $\vec{\Phi}$ and in one of our cases (054646), with one month's cough and chest pain, Strongyloides larvae in the ${ }^{\text {s }}$ faeces, normal sedimentation rate, 800 eosinophils $\overrightarrow{0}$ per cu mm, and a rising titre in the Ascaris com- $\overrightarrow{-}$ plement-fixation test, the differentation from $\vec{\sigma}$ pulmonary tropical eosinophilia was only settled by the curative effect of dithiazanine. A small series of cases was also tested in parallel using antigen $\rightarrow$ extracted from Dracunculus medinensis in the manner described above for Ascaris lumbricoides: the 0 results, and even the titres, were the same as those with the Ascaris antigen.

The tentative conclusion of this work is therefore $\vec{z}$ that a similar, and perhaps identical, nematode lipoid is present in alcoholic extracts both of Ascaris and Dirofilaria, that it is antigenic if human tissue $\mathscr{\odot}$ is penetrated, and that hyperimmunity may give ${ }^{\circ}$ cross reaction with cardiolipin antigen.

For a great deal of the recording, we are indebted to Mrs T. Sargeaunt.

\section{REFERENCES}

Buckley, J. J. C. (1958). E. Afr. med. J., 35, 493.

Danaraj, T. J., Da Silva, L. S., and Schacher, J. F. (1959). Amer. J. trop. Med. Hyg., 8, 151.

Randolph, T. G., and Stanton, C. L. (1945). Amer. J. clin. Path., tech Suppl., 9, 17.

Reay, H. A. J., Dignan, A. P., and Maunder, C. (1964). Brit. med. J., $2,553$.

Ridley, D. S. (1956). Trans. roy. Soc. trop. Med. Hyg., 50, 255.

Weingarten, R. J. (1943). Lancet, 1, 103. 